\title{
Mercury in alpine fish from four rivers in the Tibetan Plateau
}

\author{
Junjuan Shao ${ }^{1}$, Jianbo Shi ${ }^{1,2, *}, \mathrm{Bu} \mathrm{Duo}^{3}$, Chengbin $\mathrm{Liu}^{1}$, Yan Gao ${ }^{1}$, Jianjie $\mathrm{Fu}^{1}$, \\ Ruiqiang Yang ${ }^{1}$, Guibin Jiang ${ }^{1}$
}

1. State Key Laboratory of Environmental Chemistry and Ecotoxicology, Research Center for Eco-Environmental Sciences, Chinese Academy of Sciences, Beijing 100085, China

2. College of Resources and Environment, University of Chinese Academy of Sciences, Beijing 100049, China

3. Science Faculty, Tibet University, Lhasa 850000, China

\section{A R T I C L E I N F O}

Article history:

Received 14 July 2015

Revised 30 September 2015

Accepted 3 October 2015

Available online 8 December 2015

Keywords:

Mercury

Methylmercury

Fish

The Tibetan Plateau

Trophic level

Risk assessment

\begin{abstract}
A B S T R A C T
As a global pollutant, high levels of mercury $(\mathrm{Hg})$ have been found in remote ecosystem due to the long range atmospheric transport. In this study, a total of 60 fish samples were collected from four rivers across the Tibetan Plateau to study the accumulation of $\mathrm{Hg}$ in remote and high-altitude aquatic environment. The total $\mathrm{Hg}(\mathrm{THg})$ and methylmercury ( $\mathrm{MeHg}$ ) in fish muscles ranged from 11 to $2097 \mathrm{ng} / \mathrm{g}$ dry weight (dw) (average: $819 \mathrm{ng} / \mathrm{g} \mathrm{dw}$ ) and from 14 to $1960 \mathrm{ng} / \mathrm{g} \mathrm{dw}$ (average: $756 \mathrm{ng} / \mathrm{g} \mathrm{dw}$ ), respectively. Significantly positive linear relationships were observed between the THg $(r=0.591, p<0.01, n=36)$ and MeHg concentrations $(r=0.473, p<0.01, n=36)$ with the trophic level of fish from Lhasa River, suggesting trophic transfer and biomagnification of $\mathrm{Hg}$ in this aquatic ecosystem. Moreover, the THg levels in fish had significantly positive correlations with the length $(r=0.316$, $p<0.05, n=60)$ and weight $(r=0.271, p<0.05, n=60)$ of fish. The high levels of Hg were attributed to the slow growth and long lifespan of the fish under this sterile and cold environment. Risk assessment revealed that the consumption of Oxygymnocypris stewartii, Schizothorax macropogon, Schizothorax waltoni, Schizopygopsis younghusbandi and Schizothorax o'connori would lead to a high exposure to $\mathrm{MeHg}$.

(C) 2015 The Research Center for Eco-Environmental Sciences, Chinese Academy of Sciences.
\end{abstract} Published by Elsevier B.V.

\section{Introduction}

Mercury (Hg) is a toxic and global pollutant. $\mathrm{Hg}$ in the environment majorly comes from two sources, natural sources and anthropogenic sources (Jiang et al., 2006). Natural emissions mainly originate from volcanoes (Zambardi et al., 2009), geothermal activity (Gustin et al., 2008) and emissions from soil and water. Mining, smelting, coal combustion and industrial usage of $\mathrm{Hg}$ in chlor-alkali production, batteries, fluorescent lamps, medical devices and so on comprise anthropogenic sources (Pirrone et al., 2010; Streets et al., 2011). Due to the long lifetime of $\mathrm{Hg}$ in atmosphere and the ability of long range transport, Hg emitted from both natural sources and anthropogenic sources can be deposited into remote lakes and rivers, resulting in serious pollution in aquatic system (Fitzgerald et al., 1998; Miller et al., 2005; Poissant et al., 2008).

The Tibetan Plateau has an average elevation of $4000 \mathrm{~m}$ above sea level. The population in the Tibet Autonomous Region was 2.21 million in 1990 and increased to 3.00 million in 2010 (Yu et al., 2012). The total area of the Tibetan Plateau is more than 1.22 million square kilometers including $64.57 \%$ farmland, $0.05 \%$ construction land and $35.38 \%$ unused land

\footnotetext{
* Corresponding author. E-mail: jbshi@rcees.ac.cn (Jianbo Shi).
} 
(Liao et al., 2008). The geological substrate in the Tibetan Plateau is mainly igneous rock (Ma, 1998). The vegetation on the plateau is the high-cold meadow, steppe and desert vegetation (Zhang, 1978). The Tibetan Plateau locates in Asia where the world's largest anthropogenic Hg emission source exits. In 2008, the global $\mathrm{Hg}$ emissions were 2000 tons and Asia was responsible for $64 \%$ of the total emissions (1280 tons) (Streets et al., 2011). The total anthropogenic Hg emissions in China were estimated at 609 tons in 2007 (Pirrone et al., 2010). Though local industrial activities in the Tibetan Plateau were rare, the long range atmospheric transport of $\mathrm{Hg}$ had resulted in Hg pollution in this plateau (Huang et al., 2012; Loewen et al., 2007; Yang et al., 2010). The backward air mass trajectory analysis suggested that dust storm containing particulate $\mathrm{Hg}$ originated in Iran and Afghanistan and finally reached Mount Nyainqentanglha in the Tibetan Plateau after traveling over thousands of kilometers (Loewen et al., 2007). Some trace metals (Cr, Ni, Cu, $\mathrm{Zn}, \mathrm{As}$ ) in aerosols from the Nam Co region, which is located in central Tibet and covering an area of $1980 \mathrm{~km}^{2}$ at an elevation of $4718 \mathrm{~m}$, might be from South Asia over the long range atmospheric transport (Cong et al., 2007).

Some studies have investigated the Hg contamination in the Tibetan Plateau. The results showed that the Hg concentrations ranged from 1.46 to $4.99 \mathrm{ng} / \mathrm{L}$ in water from Yarlung Zangbo River (Zheng et al., 2010). The average of total gaseous mercury concentrations in ambient air in the eastern slope of Mt. Gongga, south-eastern fringe of the Tibetan Plateau, was $3.98 \mathrm{ng} / \mathrm{m}^{3}$ (from 0.52 to $21.03 \mathrm{ng} / \mathrm{m}^{3}$ ) (Fu et al., 2008). Surprisingly, the maximum concentrations of total mercury (THg) and methylmercury (MeHg) in fish from lakes of the Tibetan Plateau reached 2384 and 1610 ng/g, respectively (Yang et al., 2011). However, there are still some questions remaining unclear about the bioaccumulation and biomagnification of $\mathrm{Hg}$ in the aquatic ecosystem in the Tibetan Plateau.

The toxicity, environmental behavior and bioavailability of $\mathrm{Hg}$ depend not only on its total concentration but also its species. As one of the organic mercurial species, $\mathrm{MeHg}$ is the most toxic. Due to its lipophilicity, $\mathrm{MeHg}$ can penetrate the blood-brain barrier and finally harm central nervous system (Cheng et al., 2005, 2015; Clarkson and Magos, 2006; Winship, 1986). MeHg constitutes more than $80 \%$ of THg in fish muscle (Akagi et al., 1995; Bloom, 1992; Campbell et al., 2005; Guentzel et al., 2007; Mohan et al., 2012). Consumption of fish with elevated MeHg is the principal pathway of human exposure to $\mathrm{Hg}$ (Liang et al., 2013; Tang et al., 2015). Hence, health risk assessment on MeHg through the consumption of fish is imperative and important.

The aim of this study was to investigate the pollution status of $\mathrm{THg}$ and $\mathrm{MeHg}$ in fish samples from rivers in the Tibetan Plateau, study the trophic transfer behavior of $\mathrm{Hg}$ in remote alpine aquatic ecosystem and further evaluate potential health risk posed via fish consumption.

\section{Materials and methods}

\subsection{Sample collection}

The map of the sampling area and the locations of sampling sites are shown in Fig. 1. A total of 60 fish samples were collected from four rivers (Yarlung Zangbo River (YZR), Lhasa

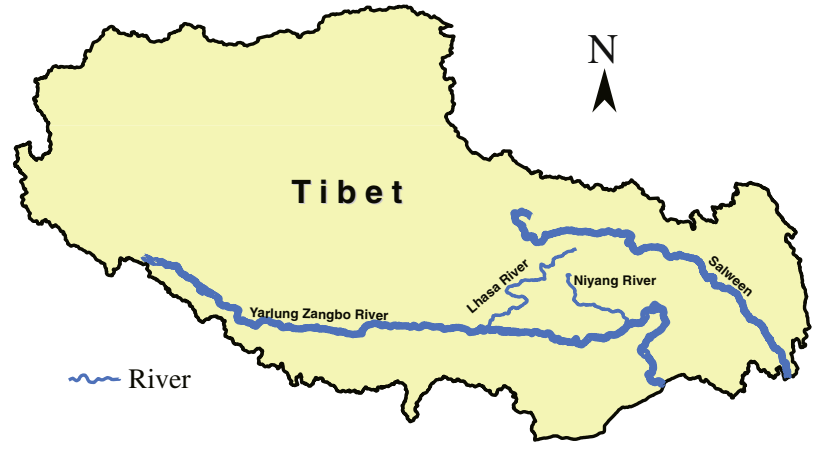

Fig. 1 - The map of the study area.

River, Salween and Niyang River) in the Tibetan Plateau in August of 2010, 2011 and 2012. YZR, the longest alpine river in China, is regarded as the mother river by Tibetan. As the largest branch of the YZR, the Lhasa River originates from Nyainqentanglha Mountain on the Tibetan Plateau and flows through Lhasa city, the provincial capital of the Tibet Autonomous Region. Salween originates from Tanggula Mountains. The Niyang River is also one branch of the YZR, which originates from the Mila Mountain and finally goes into the YZR in Nyingchi.

All fish species are unique in the Tibetan Plateau and these species belong to the family of Cyprinidae and subfamily of Schizothoracinae. Precautions were taken in order to avoid any contamination or loss during sampling. After collected, the fish samples were carried back to the laboratory as soon as possible in polyethylene zippered bags in boxes with ice. They were stored at $-20^{\circ} \mathrm{C}$ before dissection. The dorsal muscles (50 g) were dissected from each fish using clean stainless steel scalpel after the length and weight were measured. The fish samples were freeze-dried, grounded and then stored at $-20^{\circ} \mathrm{C}$ until analyzing.

\subsection{Determination of $\mathrm{THg}, \mathrm{MeHg}$ and trophic level}

The concentrations of $\mathrm{THg}$ in fish samples were determined directly with a Hydra II-C atomic absorption spectrometry (Leeman Labs, Hudson, USA). Briefly, about $0.03 \mathrm{~g}$ of grounded fish samples was weighed in a nickel boat. A certain amount of diatomite was covered on the sample to prevent the lipid from entering the instrument. The sample was burned at high temperature and all forms of mercury were reduced to elemental mercury. Then, the elemental mercury was brought and trapped onto a gold amalgam. After decomposition from the gold amalgam, the concentrations of THg were determined.

For MeHg analysis, alkaline extraction was applied (Meng et al., 2014, 2015). About $0.1 \mathrm{~g}$ of sample was weighed into an 8-mL brown glass bottle and $4 \mathrm{~mL} 25 \%(\mathrm{M} / \mathrm{V}) \mathrm{KOH} / \mathrm{CH}_{3} \mathrm{OH}$ solution was added. The bottle was then mechanically shaken for $4 \mathrm{hr}$ at $37^{\circ} \mathrm{C}$ to achieve complete extraction. The solution was centrifuged at $3000 \mathrm{r} / \mathrm{min}$ for $10 \mathrm{~min}$ after cooling down. Before being analyzed, each sample was diluted tenfold. Then, $30 \mu \mathrm{L}$ of diluents was injected into the auto sampler vial and ethylated by sodium tetraethylborate $\left(\mathrm{NaBEt}_{4}\right)$. The contents of $\mathrm{MeHg}$ were determined by purge and trap gas chromatography-atomic fluorescence spectrometry (GC-AFS) method 
Table 1 - Results of total mercury (THg) and methylmercury (MeHg) in certified reference materials (CRMs) $(n=5)$.

\begin{tabular}{lccccc} 
CRMs & \multicolumn{2}{c}{ THg (ng/g) } & & \multicolumn{2}{c}{ MeHg (ng/g) } \\
\cline { 2 - 3 } \cline { 5 - 6 } \cline { 5 - 6 } & Certified & Determined & & Certified & Determined \\
\hline TORT-2 & $270 \pm 60$ & $276 \pm 6$ & & $152 \pm 13$ & $170 \pm 4$ \\
DORM-4 & $410 \pm 55$ & $412 \pm 31$ & & $354 \pm 31$ & $356 \pm 1$ \\
\hline
\end{tabular}

with a MERX Automatic Methylmercury System (Brooks Rand Laboratories, USA).

Stable nitrogen isotope ratio $(R$, the isotopic abundance ratio of ${ }^{15} \mathrm{~N}$ and ${ }^{14} \mathrm{~N}$ ) was determined by a DELTA V Advantage Isotope Ratio Mass Spectrometer (Thermo Fisher Scientific, USA). Then, the isotopic composition $\left(\delta^{15} \mathrm{~N}, \%\right.$ ) was calculated using the following formula:

$\delta^{15} \mathrm{~N}=\left(\left(R_{\text {sample }} / R_{\text {standard }}\right)-1\right) \times 1000 \%$ 。

The trophic levels (TLs) of fish were calculated based on the nitrogen stable isotope analysis using the following formula (Fisk et al., 2001; Yuan et al., 2012):

$\mathrm{TL}=\left(\delta^{15} \mathrm{~N}_{\text {fish }}-\delta^{15} \mathrm{~N}_{\text {zooplankton }}\right) / 3.8+2$

The range of TLs was 2.60-4.12 and the average of the TLs was 3.22 .

\subsection{Quality assurance/quality control}

Reagent blanks, certified reference materials (CRMs) and sample replicates were randomly applied in the analysis for the quality control. The determined concentrations of $\mathrm{THg}$ and MeHg in two CRMs (TORT-2 and DORM-4) were in good agreement with the certified values, indicating that the method was accurate and reliable (Table 1).

\subsection{Statistical analysis}

Multiple statistical analysis methods were used with SPSS 20.0 to find the distribution patterns of $\mathrm{THg}$ and $\mathrm{MeHg}$ in fish from the Tibetan Plateau. One-way ANOVA analysis was applied to compare the THg concentrations in different fish species from the Lhasa River. Correlation Analysis was applied to find the correlations among the $\mathrm{THg}$ and $\mathrm{MeHg}$ contents and the length, weight and TLs of the fish.

\section{Results and discussion}

\subsection{Concentrations of $\mathrm{THg}$ and $\mathrm{MeHg}$ in fish}

Concentrations of THg and MeHg and related information of the samples are listed in Table 2. The THg concentrations in fish collected in this work ranged from 11 to $2097 \mathrm{ng} / \mathrm{g}$ (dw) with an average of $819 \mathrm{ng} / \mathrm{g}$ (Table 3). The lowest and the highest THg concentrations were found in the Silurus asotus from Salween and Oxygymnocypris stewartii from YZR, respectively. The concentrations of MeHg ranged from 14 to $1960 \mathrm{ng} / \mathrm{g}$ dw with an average of $756 \mathrm{ng} / \mathrm{g} \mathrm{dw}$. The mean ratio of $\mathrm{MeHg}$ in $\mathrm{THg}$ was $95.6 \%$. Therefore, MeHg showed a significantly positive correlation ( $r=0.979, p<0.01, n=60)$ with THg.

The concentrations of THg and MeHg in fish in this work were comparable with those values in previous studies (Yang et al., 2011, 2013; Zhang et al., 2014) conducted in the Tibetan Plateau. The THg concentrations in fish from French Pyrénées mountain lakes were also in the same order of magnitude with those in the Tibetan Plateau (Blais et al., 2006). Surprisingly, the average value of THg in fish from this pristine Tibetan Plateau was even higher than that in Hg-contaminated reservoir in Guizhou, China, where the concentrations of total $\mathrm{Hg}$ in fish tissue were in the range of 20-1270 ng/g dry weight (with an average of $265 \mathrm{ng} / \mathrm{g}$ ) (Liu et al., 2012).

\subsection{Accumulation of $\mathrm{Hg}$ in fish}

THg and MeHg can biomagnify in fish through the food chain. The trophic levels (TLs) of the fish were calculated based on the nitrogen stable isotope analysis. The calculated TLs for all fish in the present study were in the range 2.60-4.12. In order to explore the biomagnification of $\mathrm{Hg}$ in fish from the Tibetan Plateau, the correlation analysis between $\mathrm{Hg}$ concentration (including $\mathrm{THg}$

Table 2 - Fish sample information and average concentrations of $\mathrm{THg}$ and $\mathrm{MeHg}$ in fish muscles from rives of Tibetan Plateau.

\begin{tabular}{|c|c|c|c|c|c|c|c|c|}
\hline Sites & Species & Number & $\begin{array}{c}\text { Length } \\
\text { (cm) }\end{array}$ & $\begin{array}{l}\text { Weight } \\
\text { (g) }\end{array}$ & Trophic Level & $\begin{array}{l}\text { Lipid } \\
(\%)\end{array}$ & $\begin{array}{c}\text { THg } \\
\text { (ng/g, dw) }\end{array}$ & $\begin{array}{c}\mathrm{MeHg} \\
\text { (ng/g, dw) }\end{array}$ \\
\hline \multirow[t]{5}{*}{ Lhasa River } & Oxygymnocypris stewartii & 13 & 36.7 & 433.8 & 3.65 & 13.64 & 1136 & 1031 \\
\hline & Schizothorax macropogon & 6 & 29.5 & 260.9 & 3.01 & 9.65 & 941 & 929 \\
\hline & Schizothorax o'connori & 6 & 34.5 & 361.1 & 2.95 & 13.98 & 316 & 281 \\
\hline & Schizopygopsis younghusbandi & 5 & 31.8 & 269.9 & 2.75 & 14.01 & 416 & 390 \\
\hline & Schizothorax waltoni & 6 & 33.4 & 333.4 & 3.29 & 15.64 & 1461 & 1331 \\
\hline Salween & Silurus asotus & 4 & 18.8 & 91.1 & 2.80 & - & 20 & 22 \\
\hline \multirow[t]{4}{*}{ Niyang River } & Schizothorax o'connori & 4 & 40.3 & 594.1 & 3.20 & 7.62 & 416 & 364 \\
\hline & Schizothorax waltoni & 3 & 22.7 & 157.2 & 3.03 & 12.54 & 279 & 276 \\
\hline & Schizothorax macropogon & 2 & 25.5 & 274.3 & 3.13 & 6.97 & 662 & 649 \\
\hline & Oxygymnocypris stewartii & 1 & 34.0 & 401.0 & 3.82 & 11.43 & 1344 & 1158 \\
\hline \multirow[t]{5}{*}{ Yarlung Zangbo } & Schizopygopsis younghusbandi & 5 & 29.4 & 222.0 & 3.42 & - & 1150 & 1033 \\
\hline & Schizothorax macropogon & 2 & 30.5 & 348.4 & 3.13 & 14.40 & 877 & 877 \\
\hline & Oxygymnocypris stewartii & 1 & 32.0 & 365.8 & 3.65 & 15.55 & 1826 & 1961 \\
\hline & Schizothorax o'connori & 1 & 28.0 & 378.4 & 3.22 & 6.96 & 227 & 258 \\
\hline & Schizothorax waltoni & 1 & 32.0 & 396.1 & 3.33 & 15.44 & 1189 & 1367 \\
\hline
\end{tabular}


Table 3 - Comparison of THg concentrations in fish muscle from other remote areas.

\begin{tabular}{lllll}
\multicolumn{1}{c}{ Study sites } & \multicolumn{1}{c}{ THg $(\mathrm{ng} / \mathrm{g}, \mathrm{dw})$} & Number & Years & \multicolumn{1}{c}{ Reference } \\
\hline Rivers and lakes, Tibetan Plateau & $502.5(125.5-6090)^{\mathrm{a}}$ & 166 & 2009,2010 & Zhang et al. (2014) \\
Niyang river, Tibetan Plateau & $129(85-217)$ & 8 & 2007 & Yang et al. (2013) \\
Lakes, Tibetan Plateau & $145(243-2384)$ & 62 & $2006-2007$ & Yang et al. (2011) \\
Stewart lake, sub-Arctic & $350-2950^{\mathrm{a}}$ & 244 & 1999 & Power et al. (2002) \\
Lakes in Pyrénées, French & $1515 \pm 935^{\mathrm{a}}$ & 37 & 2001 & Blais et al. (2006) \\
Lancaster sound, Arctic & $190-240$ & 13 & 1992 & Atwell et al. (1998) \\
Admiralty bay, Antarctica & $16.0-16.3$ & 11 & 2004 & Dos et al. (2006) \\
Svalbard, Arctic & n.d. $-100^{\mathrm{a}}$ & 30 & 2006 & Jæger et al. (2009) \\
Terra Nova bay, Antarctica & $92.6-907.3$ & 6 & 2006 & Maggi et al. (2009) \\
Rivers, Tibetan Plateau & $819(11-2097)$ & 60 & $2010-2012$ & This study \\
\hline
\end{tabular}

a The concentrations (ng/g, wet weight) were converted to (ng/g, dry weight) based on the water content in muscle of $80 \%$.

b Not detected.

and $\mathrm{MeHg}$ ) and TLs were performed. The correlation analysis was only performed among the data from Lhasa River, due to the limited number of samples and fish species in other three rivers. Significantly positive linear relationships were found between THg and TL ( $r=0.591, p<0.01, n=36)$, MeHg and TL $(r=0.473$, $p<0.01, n=36$ ) (Fig. 2), suggesting trophic transfer and biomagnification of $\mathrm{Hg}$ in fish from Lhasa River. Similar results were also observed for $\mathrm{Hg}$ in Arctic marine food chain (Atwell et al., 1998; Campbell et al., 2005), sub-Arctic lake (Power et al., 2002) and in Lake Murray, Papua New Guinea (Bowles et al., 2001). Contents of THg and MeHg in fish from Lhasa River decreased on the descending order: Schizothorax waltoni > Schizothorax macropogon and O. stewartii > Schizopygopsis younghusbandi and Schizothorax o'connori (one-way ANOVA analysis, $p<0.05$ ) (Fig. 3). Overall, the contents of THg and MeHg in the muscles increased along with the trophic levels.

Trophic magnification factors (TMFs) have been applied to determine the biomagnification of pollutant and the extent of biomagnification, which were calculated as the antilogarithm of the slope of the linear regression of the log-transformed concentration on TLs (Foster et al., 2012; Jæger et al., 2009). Normally, TMF higher than 1 was considered occurring in the biomagnification. In this work, the TMF for THg was 2.64 and for $\mathrm{MeHg}$ was 2.72, suggesting that both THg and $\mathrm{MeHg}$ could be biomagnified in fish from the Lhasa River. The TMFs for
THg and MeHg in this study were lower than those in an Arctic marine ecosystem in Svalbard (Jæger et al., 2009). Moreover, the TMF for MeHg was higher than that for $\mathrm{THg}$, indicating that $\mathrm{Hg}$ was biomagnified mainly in the form of $\mathrm{MeHg}$.

Fish length has been suggested as an important factor influencing fish Hg levels (Kamman et al., 2005; Matthew et al., 2010). In this study, fish length had a significantly positive correlation $(r=0.316, p<0.05, n=60)$ with THg concentrations in fish muscle tissues. This result was consistent with the previous reports of other studies $(r=0.48, p<0.05, n=23$, Farias et al., 2005; $r=0.8459, p<0.0001, n=58$, Farkas et al., 2003). Moreover, significantly positive linear relationships $(r=0.271, p<0.05, n=60)$ were also found between THg concentrations and fish weight, indicating that weight partly influenced THg contents in fish.

\subsection{Risk of $\mathrm{MeHg}$ in fish}

The Joint FAO/WHO Expert Committee on Food Additives established provisional tolerable weekly intakes (PTWIs) for $\mathrm{MeHg}$ at $1.6 \mu \mathrm{g} / \mathrm{kg}$ body weight (WHO, 2010).

The consumption rate was $24.8 \mathrm{~g} /$ day according to the surveying results of the national diet and nutrition in China in 2002 (Zhai and Yang, 2006). The body weight for adults was assumed to be $60 \mathrm{~kg}$. The following formula (USEPA, United
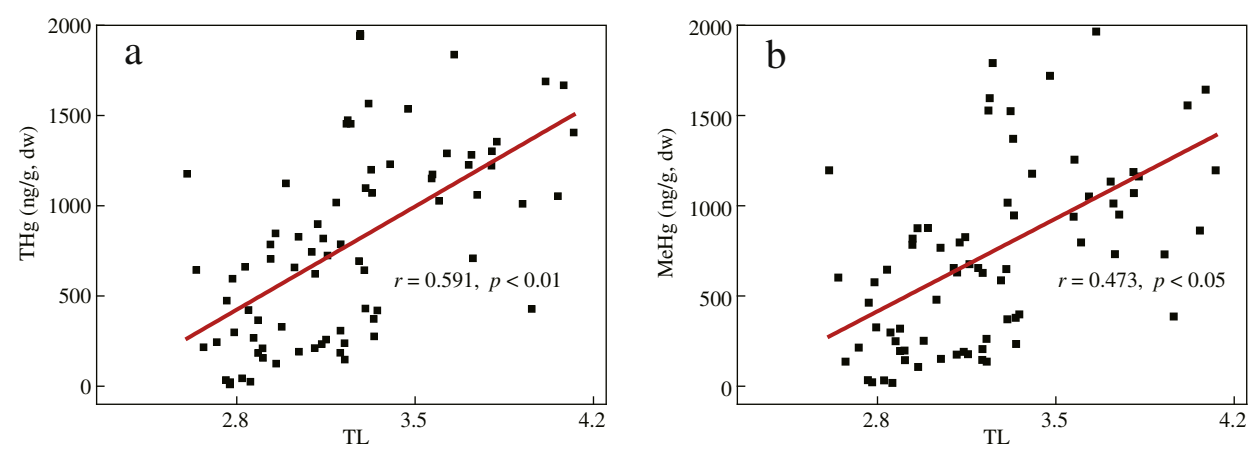

Fig. 2 - Correlations between THg and MeHg concentrations and trophic level (TL) for fish from Lhasa River. 


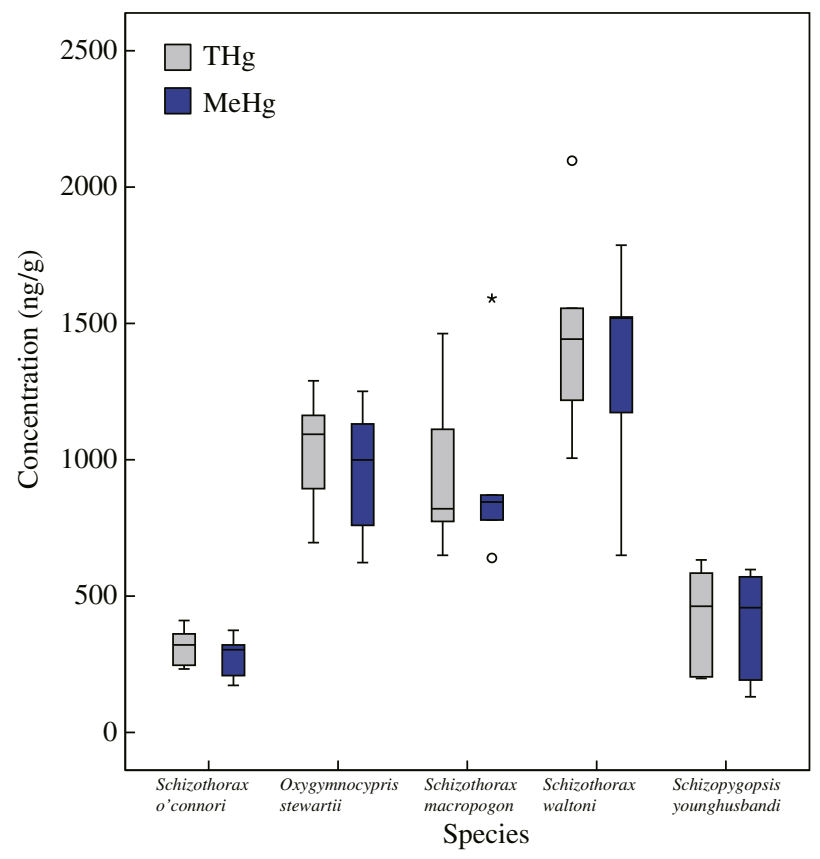

Fig. 3 - Boxplots of THg and MeHg in different fish species from Lhasa River.

State Environmental Protection Agency, 2000) was used to estimate the daily intakes of MeHg via the consumption of fish:

Estimated daily intake (EDI) = fish consumption (g/day)

$\times \mathrm{MeHg}$ concentrations $(\mu \mathrm{g} / \mathrm{g}) /$ average body weight $(\mathrm{kg})$

The estimated weekly intake (EWI) was calculated from the formula:

$\mathrm{EWI}=\mathrm{EDI} \times 7$

The results of the EWIs of MeHg are shown in Fig. 4. All EWIs of the O. stewartii and S. macropogon exceeded the PTWI of MeHg.

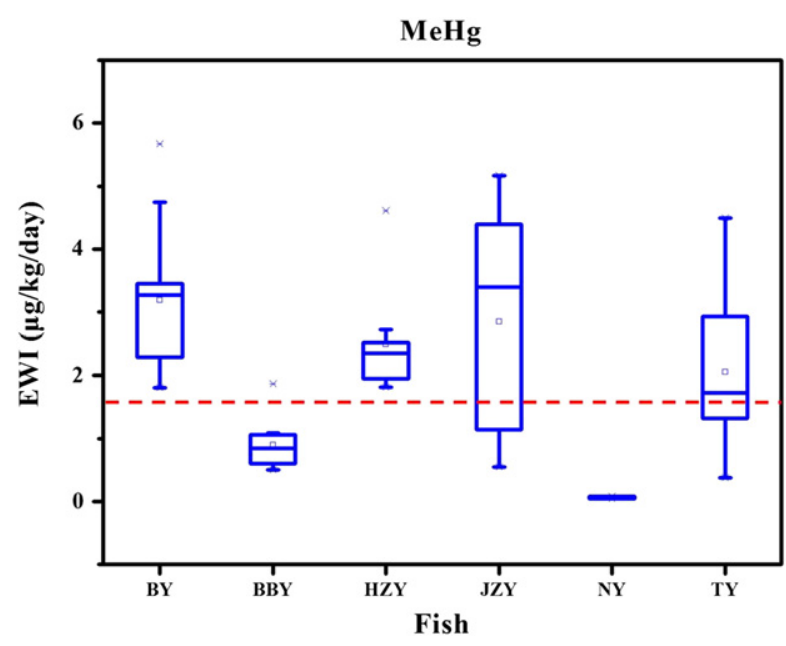

PTWI

Fig. 4 - Estimated weekly intakes (EWIs) of MeHg through consumption of fish by adults. PTWI: provisional tolerable weekly intakes for $\mathrm{MeHg}(1.6 \mu \mathrm{g} / \mathrm{kg}$ body weight by the Joint FAO/WHO Expert Committee on Food Additives).
Consumption of $70 \%$ of the S. waltoni and S. younghusbandi, $9 \%$ of the S. o'connori would result in the EWI of MeHg exceeding the PTWI (1.6 $\mu \mathrm{g} / \mathrm{kg}$ body weight) for adults. The EWIs of MeHg for adults for all S. asotus were lower than the PTWI value. The results suggested that consumption of some species of fish from the cold and high-altitude Tibetan Plateau would lead to a high exposure to $\mathrm{MeHg}$.

\section{Conclusion}

The bioaccumulation of $\mathrm{Hg}$ in remote and high altitude aquatic ecosystem in the Tibetan Plateau was studied. The concentrations of THg and MeHg in fish from rivers in the Tibetan Plateau were relatively high. The MeHg concentrations were significantly positively correlated with trophic levels (TLs), while THg concentrations were significantly positively correlated with TLs, the length and weight of fish. The results of this study indicated that the consumption of $O$. stewartii, S. macropogon, S. waltoni, S. younghusbandi and S. o'connori in this area might impose health risk.

\section{Acknowledgment}

This work was supported by the National Basic Research Program (973) of China (Nos. 2013CB430004, 2014CB460612), the National Natural Science Foundation of China (Nos. 41422306, 21120102040) and the Young Scientists Fund of Research Center for Eco-Environmental Sciences (No. RCEES-QN-20130007F).

\section{R E F E R E N C E S}

Akagi, H., Malm, O., Kinjo, Y., Harada, M., Branches, F.J.P., et al., 1995. Methylmercury pollution in the Amazon, Brazil. Sci. Total Environ. 175, 85-95.

Atwell, L., Hobson, K.A., Welch, H.E., 1998. Biomagnification and bioaccumulation of mercury in an arctic marine food web: insights from stable nitrogen isotope analysis. Can. J. Fish. Aquat. Sci. 55, 1114-1121.

Blais, J.M., Charpentié, S., Pick, F., Kimpe, L.E., Amand, A.S., Regnault-Roger, C., 2006. Mercury, polybrominated diphenyl ether, organochlorine pesticide, and polychlorinated biphenyl concentrations in fish from lakes along an elevation transect in the French Pyrénées. Ecotoxicol. Environ. Saf. 63, 91-99.

Bloom, N.S., 1992. On the chemical form of mercury in edible fish and marine invertebrate tissue. Can. J. Fish. Aquat. Sci. 49, 1010-1017.

Bowles, K.C., Apte, S.C., Maher, W.A., Kawei, M., Smith, R., 2001. Bioaccumulation and biomagnification of mercury in Lake Murray, Papua New Guinea. Can. J. Fish. Aquat. Sci. 58, 888-897.

Campbell, L.M., Norstrom, R.J., Hobson, K.A., Muir, D.C.G., Backus, S., Fisk, A.T., 2005. Mercury and other trace elements in a pelagic Arctic marine food web (Northwater Polynya, Baffin Bay). Sci. Total Environ. 351-352, 247-263.

Cheng, J.P., Yang, Y.C., Hu, W.X., Yang, L., Wang, W.H., Jia, J.P., et al., 2005. Effect of methylmercury on some neurotransmitters and oxidative damage of rats. J. Environ. Sci. 17, 469-473.

Cheng, J.P., Masatake, F., Bo, D.D., 2015. Assessing pre/post-weaning neurobehavioral development for perinatal exposure to low doses of methylmercury. J. Environ. Sci. 38, 36-41. 
Clarkson, T.W., Magos, L., 2006. The toxicology of mercury and its chemical compounds. Crit. Rev. Toxicol. 36, 609-662.

Cong, Z.Y., Kang, S.C., Liu, X.D., Wang, G.F., 2007. Elemental composition of aerosol in the Nam Co region, Tibetan Plateau, during summer monsoon season. Atmos. Environ. 41, 1180-1187.

Dos, S., Isaac, R., Silva, F., Emmanoel, V., Schaefer, C., Maria, S., et al., 2006. Baseline mercury and zinc concentrations in terrestrial and coastal organisms of Admiralty Bay, Antarctica. Environ. Pollut. 140, 304-311.

Farias, R.A., Hacon, S., Campos, R.C., Argento, R., 2005. Mercury contamination in fanned fish setup on former garimpo mining areas in the Northern Mato Grosso State, Amazonian region, Brazil. Sci. Total Environ. 348, 128-134.

Farkas, A., Salánki, J., Specziár, A., 2003. Age- and size-specific patterns of heavy metals in the organs of freshwater fish Abramis brama L. populating a low-contaminated site. Water Res. 37, 959-964.

Fisk, A.T., Hobson, K.A., Norstrom, R.J., 2001. Influence of chemical and biological factors on trophic transfer of persistent organic pollutants in the Northwater Polynya Marine Food Web. Environ. Sci. Technol. 35, 732-738.

Fitzgerald, W.F., Engstrom, D.R., Mason, R.P., Nater, E.A., 1998. The case for atmospheric mercury contamination in remote areas. Environ. Sci. Technol. 32, 1-7.

Foster, K.L., Stern, G.A., Pazerniuk, M.A., Hickie, B., Walkusz, W., Wang, F.Y., et al., 2012. Mercury biomagnification in marine zooplankton food webs in Hudson Bay. Environ. Sci. Technol. 46, 12952-12959.

Fu, X.W., Feng, X.B., Zhu, W.Z., Wang, S.F., Lu, J.L., 2008. Total gaseous mercury concentrations in ambient air in the eastern slope of Mt. Gongga, South-Eastern fringe of the Tibetan plateau, China. Atmos. Environ. 42, 970-979.

Guentzel, J.L., Portilla, E., Keith, K.M., Keith, E.O., 2007. Mercury transport and bioaccumulation in riverbank communities of the Alvarado Lagoon System, Veracruz State, Mexico. Sci. Total Environ. 388, 316-324.

Gustin, M.S., Lindberg, S.E., Weisberg, P.J., 2008. An update on the natural sources and sinks of atmospheric mercury. Appl. Geochem. 23, 482-493.

Huang, J., Kang, S.C., Guo, J.M., Zhang, Q.G., Xu, J.Z., Jenkins, M.G., et al., 2012. Seasonal variations, speciation and possible sources of mercury in the snowpack of Zhadang glacier, Mt. Nyainqentanglha, southern Tibetan Plateau. Sci. Total Environ. 429, 223-230.

Jæger, I., Hop, H., Gabrielsen, G.W., 2009. Biomagnification of mercury in selected species from an Arctic marine food web in Svalbard. Sci. Total Environ. 407, 4744-4751.

Jiang, G.B., Shi, J.B., Feng, X.B., 2006. Mercury pollution in China. Environ. Sci. Technol. 40, 3672-3678.

Kamman, N.C., Burgess, N.M., Driscoll, C.T., Simonin, H.A., Goodale, W., Linehan, J., et al., 2005. Mercury in freshwater fish of northeast North America - a geographic perspective based on fish tissue monitoring databases. Ecotoxicology 14, 163-180.

Liang, P., Qin, Y.Y., Zhang, C., Zhang, J., Cao, Y.C., Wu, S.C., et al., 2013. Plasma mercury levels in Hong Kong residents: in relation to fish consumption. Sci. Total Environ. 463-464, 1225-1229.

Liao, X.Y., Chen, Z.J., Wang, H.M., Dai, H., 2008. Study on the functional division of land utilization in Tibet Autonomous Region. J. Anhui Agri. Sci. 36, 2847-2849 (2923).

Liu, B., Yan, H.Y., Wang, C.P., Li, Q.H., Guédron, S., Spangenberg, J.E., et al., 2012. Insights into low fish mercury bioaccumulation in a mercury-contaminated reservoir, Guizhou, China. Environ. Pollut. 160, 109-117.

Loewen, M., Kang, S.C., Armstrong, D., Zhang, Q.G., Tomy, G., Wang, F.Y., 2007. Atmospheric transport of mercury to the Tibetan plateau. Environ. Sci. Technol. 41, 7632-7638.

Ma, G.Q., 1998. Basic regional geological features of Tibet. Regional. Geology. China 17, 16-24.
Maggi, C., Berducci, M.T., Bianchi, J., Giani, M., Campanella, L., 2009. Methylmercury determination in marine sediment and organisms by Direct Mercury Analyser. Anal. Chim. Acta 641, 32-36.

Matthew, M.C., Ray, W.D., David, R.C., K David, H., 2010. Factors influencing mercury accumulation in three species of forage fish from Caddo Lake, Texas, USA. J. Environ. Sci. 8, 1158-1163.

Meng, M., Li, B., Shao, J.J., Wang, T., He, B., Shi, J.B., et al., 2014. Accumulation of total mercury and methylmercury in rice plants collected from different mining areas in China. Environ. Pollut. 184, 179-186.

Meng, M., Shi, J.B., Liu, C.B., Zhu, N.L., Shao, J.J., He, B., et al., 2015. Biomagnification of mercury in mollusks from coastal areas of the Chinese Bohai Sea. RSC Adv. 5, 40036-40045.

Miller, E., Vanarsdale, A., Keeler, G., Chalmers, A., Poissant, L., Kamman, N., et al., 2005. Estimation and mapping of wet and dry mercury deposition across northeastern North America. Ecotoxicology 14, 53-70.

Mohan, M., Deepa, M., Ramasamy, E.V., Thomas, A.P., 2012. Accumulation of mercury and other heavy metals in edible fishes of Cochin backwaters, Southwest India. Environ. Monit. Assess. 184, 4233-4245.

Pirrone, N., Cinnirella, S., Feng, X., Finkelman, R.B., Friedli, H.R., Leaner, J., et al., 2010. Global mercury emissions to the atmosphere from anthropogenic and natural sources. Atmos. Chem. Phys. 10, 5951-5964.

Poissant, L., Zhang, H.H., Canário, J., Constant, P., 2008. Critical review of mercury fates and contamination in the arctic tundra ecosystem. Sci. Total Environ. 400, 173-211.

Power, M., Klein, G.M., Guiguer, K., Kwan, M.K.H., 2002. Mercury accumulation in the fish community of a sub-Arctic lake in relation to trophic position and carbon sources. J. Appl. Ecol. 39, 819-830.

Streets, D.G., Devane, M.K., Lu, Z., Bond, T.C., Sunderland, E.M., Jacob, D.J., 2011. All-time releases of mercury to the atmosphere from human activities. Environ. Sci. Technol. 45, 10485-10491.

Tang, W., Cheng, J.P., Zhao, W.C., Wang, W.H., 2015. Mercury levels and estimated total daily intakes for children and adults from an electronic waste recycling area in Taizhou, China: Key role of rice and fish consumption. J. Environ. Sci. 27, 107-115.

USEPA (United State Environmental Protection Agency), 2000. Guidance for Assessing Chemical Contaminant for Use in Fish Advisories. EPA, Washington, DC.

WHO (World Health Organization), 2010. Joint FAO/WHO Expert Committee on Food Additives (JECFA). Seventy-second meeting, Rome, pp. 16-25 (February 2010).

Winship, K.A., 1986. Organic mercury-compounds and their toxicity. Adverse Drug React. Toxicol. Rev. 5, 141-180.

Yang, H.D., Battarbee, R.W., Turner, S.D., Rose, N.L., Derwent, R.G., Wu, G.J., et al., 2010. Historical reconstruction of mercury pollution across the Tibetan Plateau using lake sediments. Environ. Sci. Technol. 44, 2918-2924.

Yang, R.Q., Jing, C.Y., Zhang, Q.H., Wang, Z.H., Wang, Y.W., Li, Y.M., et al., 2011. Polybrominated diphenyl ethers (PBDEs) and mercury in fish from lakes of the Tibetan Plateau. Chemosphere 83, 862-867.

Yang, R.Q., Jing, C.Y., Zhang, Q.H., Jiang, G.B., 2013. Identifying semi-volatile contaminants in fish from Niyang River, Tibetan Plateau. Environ. Earth Sci. 68, 1065-1072.

Yu, C.Q., Zhang, Y.J., Claus, H., Zeng, R., Zhang, X.Z., Wang, J.S., 2012. Ecological and environmental issues faced by a developing Tibet. Environ. Sci. Technol. 46, 1979-1980.

Yuan, B., Wang, T., Zhu, N.L., Zhang, K.G., Zeng, L.X., Fu, J.J., et al., 2012. Short chain chlorinated paraffins in mollusks from coastal waters in the Chinese Bohai Sea. Environ. Sci. Technol. 46, 6489-6496.

Zambardi, T., Sonke, J.E., Toutain, J.P., Sortino, F., Shinohara, H., 2009. Mercury emissions and stable isotopic compositions at Vulcano Island (Italy). Earth Planet. Sci. Lett. 277, 236-243. 
Zhai, F., Yang, X., 2006. A Survey on the Chinese National Health and Nutrition II: The National Diet and Nutrition in 2002. People's Medical Publishing House, Beijing, pp. 21-23.

Zhang, X.S., 1978. The plateau zonality of vegetation in Xizang. Acta Bot. Sin. 20, 140-149.

Zhang, Q.G., Pan, K., Kang, S.C., Zhu, A., Wang, W.X., 2014. Mercury in wild fish from high-altitude aquatic ecosystems in the Tibetan Plateau. Environ. Sci. Technol. 48, 5220-5228.
Zheng, W., Kang, S.C., Feng, X.B., Zhang, Q.G., Li, C.L., 2010. Mercury speciation and spatial distribution in surface waters of the Yarlung Zangbo River, Tibet. Chin. Sci. Bull. 55, 2697-2703. 